\title{
Personal maturity as sanogenic potential of experiencing crisis conditions by air transport managers
}

\author{
Liubov Pomytkina, ${ }^{1, *}$,Valentyna Voloshyna $^{2}$, Alexandra Blavdzevych ${ }^{2}$, and Alexandr \\ Rykov $^{1}$ \\ ${ }^{1}$ National Aviation University of Ukraine, Liubomyra Huzara ave., 1, 03058, Kyiv, Ukraine \\ ${ }^{2}$ National Pedagogical University M.P. Drahomanov, Kyiv, Ukraine
}

\begin{abstract}
The article highlights the results of theoretical and empirical research of personal sanogenity of experiencing crisis conditions by air transport managers. The aim of the research is the empirical study of personal maturity development of air transport managers, their psychological resourcefulness, ability to self-development and scale of sanogenity of personal maturity of air transport managers experiencing unconventional crisis inflicted by COVID-19 pandemic. To assess the level of personal maturity, the Personal Maturity Questionnaire was applied (O.S.Shtepa). Level of actualizing of the personal psychological resources was studied through method of the Psychological Resourcefulness Questionnaire (O.S.Shtepa). To clarify the contents of the need for selfdevelopment as the potential of subjectivity, the method of Disposition Characteristics of Personal Self-Development was applied. (S.B.Kuzikova). The outcomes of the empirical research have discovered that air transport managers do not always have sufficient level of personal maturity development which is defined neither by age factor nor by amassed experience. Sanogenity of personal maturity for this social group is determined by their resourcefulness development level and ability to self-development. Successfulness in career development is not equivalent to manager personal maturity development level. Subjective assessment of successfulness and maturity made by managers themselves shows that $71.2 \%$ respondents do not reveal their satisfactory personal maturity. However, the majority of them is characterized with sufficient psychological resourcefulness having at the same time poor selfdevelopment ability. In the process of psychocorrection the sanogenic potential of personal maturity is actualized through raising selfdevelopment ability, reducing tension and traumatization of personality experiencing unconventional crisis.
\end{abstract}

\section{Introduction}

World pandemic inflicted by COVID-19 which the humankind faces today has generated an array of psychological problems of the follow-up, enduring and overcoming of

*Corresponding author: Lyubvit@ukr.net 
COVID crisis by personality. Overall the current situation consists not only of subjective anxieties of each person but of multi-vector crisis content components, its economic, political, social and other aspects. Life seems to come to a standstill but it proceeds its inert movement. Amid the information pressure, stressfulness, unpredictability, unexpectedness, time uncertainty, sense and value of being becomes ever more important for each personality. The majority resorts to reframing, re-evaluation, search for the new reserves and resources of its own being. Existential dimensions become key benchmarks: "Who am I now?", "Who was I before", "Whom do I want to be after pandemic?", "Is my business worthwhile continuing in post-Covid life?" etc. All those questions and other more in-depth important questions rise for the post-pandemic personality.

Pandemic like any other crisis serves as a test for the society and each society member. Current crisis requires global research of social transformation processes, re-evaluation of axiological and deontological judgements of the humankind. In the wake of turmoil focus should be kept on personal crises of personality which affected by global developments can intensify, become prolonged and be less predictable in terms of solutions.

In this context we believe it is viable to research personal states and feelings of air transport managers. They determined directions of the society development creating new ideas, shapes of social interaction, prospects of an economic sector development etc. outlining and presenting in their actions image of successful and effective personality. Once finding themselves in uncertainty and facing the risk of business loss which was previously sense of life, loss of sense of being and re-evaluation of the concept of success, those personalities happen to stick in existential crisis. To what extent are they effective in enduring and overcoming this crisis? Which personal resources help them to adapt to the new conditions of uncertainty, to transform their professional activity sectors with an aim of maintaining social and personal welfare amid pandemic and recovery afterwards? Number of successful life and business examples will influence pathway of the future country development.

Hypothetically it should be emphasized that the level of personal maturity determines the scale of the process effectiveness of enduring and overcoming of the crisis by personality. Personality experiencing crisis should identify its value senses, motives and resources which will act as sanogenic personal potential in the future. Fully mature personality unlike diffused maturity personality has different scale of sanogenity. In view of this the object of our research is personal maturity of air transport managers.

Purpose of research: to conduct empiric research of the development level of personal maturity of air transport managers; to assess their psychological resources and selfdevelopment ability and to determine the scale of sanogenity of personal maturity of managers enduring unconventional crisis inflicted by COOVID-19 pandemic.

\section{Methods}

To study scale of personal maturity of personality and to determine its sanogenity empiric research of scales of managers' personal maturity was carried out. Its connection with potential and striving for self-development of air transport managers was defined. Research participants are 57 adult persons aged from 30 to 55. They requested psychological assistance from the psychology consultant in finding life sense benchmarks and motivations in the current uncertainty, under risk of business loss and consequently with the feeling of loss of oneself and complicated new goal-setting. Top managers and owners of SMEs were invited to participate in the research and they recognized themselves subjectively as successful and accomplished professionals during the first interview.

To assess the level of personal maturity, the Personal Maturity Questionnaire was applied (Shtepa, 2008). Level of actualizing of the personal psychological potential was 
studied through method of the Psychological Resourcefulness Questionnaire (Shtepa, 2018). To clarify the contents of the need for self-development as the potential of subjectivity, the method of Disposition Characteristics of Personal Self-Development was applied (Kuzikova, 2017).

Analysis of the obtained outcomes allowed assessment of the overall level of the personal maturity of managers and defining of correlation of their personal maturity with psychological resourcefulness and self-development ability which contributed to detection of sanogenity scale of personal maturity on the stage of crisis.

Validity and reliability of the research results are ensured through comprehensive application of the appropriate research methods, mathematics statistical methods, combination of quantity and quality analysis of the obtained results etc.

Ethical issues. Participants of the psychological experimental research agreed to participate on their free will. They signed the consents on data processing and participation. The experimental research was conducted in compliance with the respect to human rights and ethical principles.

\section{Results}

It should be stressed that managers being pro-active part of civil society feel extreme pressure in the wake of the crisis both from the outer world (social environment) and inner (personal) anxieties. Psychological dimension localizes it within a question: can the personal compensatory functions endure such double pressure maintaining its viability and effectiveness for the future. It seems fair to say that world crisis inflicted by COVID-19 pandemic becomes particular individual experience of the need for reframing of its life scenario, its rights, freedoms and responsibility for itself and its close ones. Each personality faces the task of finding its own inner resources and abilities which could serve as sanogenic potential for the further life.

Modern psychological research (D’Amour, Harris, Berti, \& Keshavarz, 2021, Pomytkina and others, 2020) dedicated to personal development treats personal maturity as ability to hit the ultimate peaks of life and to withstand life hardships as underlying such potential $[8,11]$.

It is of common knowledge that personal maturity is the most complicated and the least studied aspect of maturity. E.g. A.Rean (2006) differentiated four components of personal maturity: responsibility, tolerance, self-development and integrity. The integrity includes positive cognitions and positive perception of environment. Therefore, the scientist states that mature personality is characterized with responsibility, tolerance which serve as a basis for its value-conscious approach to the society, to itself and other important issues. Along with it, mature personality is in the constant movement, does not rest and experiences enjoyment if only potential abilities are revealed, personal skills are developed and selfimprovement opportunities are found.

Bernard Lievegoed (1994) claims that a person characterized with wisdom, amiability, self-awareness, tolerance and forgivingness can be treated as mature. Later on C.S.Hall and G.Lindsey (1999) widened the scope of characteristics ascribing ability for positive social relations, realistic vision of the environment, skills of self-cognition and self-development and certain life philosophy to the personal maturity.

O.Shtepa (2008) defined mature personality as one who is resourceful i.e. has ability to independently find own forces to overcome life circumstances. The scientist believes that mature personality finds potential for recovery and surmounting of crisis in ability to selfdevelopment, transcendence and adaptation to the new conditions by means of selfimprovement, ability to go beyond the fixed life regulations and retaining of inner integrity, personal sense and ego-identity. 
On the other hand, every unconventional crisis is not only fraught with losses but has new looming opportunities. R. May (2008) argued that "crisis is the necessary stress for people which forces them to quit sticking to blatant imposed dogmas, encourages to dispose stockpile of delusions and triggers to learn the actual truth about themselves". Instead, reframing of value priorities, loss of conventional inner and outer invariables, awareness of the need for changes ("life will never be the same as before") lead primarily to disbalance, loss of full-fledged functioning and deepen personal awareness of its own imperfectness and incompetence. Personality endures moments of instability in such situations and tries to choose the only promising and less pernicious pathway of the future from the emotional and vectoral variants (Pomytkina and others, 2020) [12]. It is on this stage that the success of the personality's crisis enduring is defined, first and foremost, by the level of its personal maturity. It is a kind of efficiency test of to what extent its world is real or imaginary.

It has been already stated that all empiric research participants perceive and assess themselves as successful, active and reputable business persons. To set the goals of the future psychocorrection program the respondents were invited to assess the following traits: level of personal maturity, self-development ability as dynamic potential of personality to change, psychological resourcefulness as essential component of the overall potential which reflects available energy to adaptation.

The method Personal Maturity Questionnaire elaborated by O.Shtepa aimed at evaluation of personal maturity development revealed overall level and scale of 10 structural components of the personal maturity of the respondents: responsibility, decentration, depth of anxieties, life philosophy, tolerance, self-reliance, rapport, selfacceptance, creativity, synergy.

According to the manuals of the questionnaire, high level of personal maturity is in place, such traits as responsibility, life philosophy, creativity, self-reliance are on the high level $(8-10 \mathrm{sn})$, other traits are on the middle level; proper level - such traits as life philosophy and self-reliance are on the middle level (4-7 sn), other traits are on the middle level, there are traits which are probably on the low level (1-3 sn); critical level - life philosophy and self-reliance are on the low level (1-3 sn), other specifications are on the low level and there are specifications which are probably on the low level (1-3 sn).

To summarize the results, it should be noted that $7.5 \%$ respondents within the group have high level of personal maturity, $21.3 \%$ - proper; $71.2 \%$ - critical (Figure 1).

\section{Levels of personal maturity}

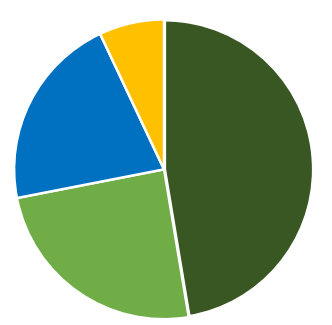

\section{- Critical 1 - Critical 2 Proper $\square$ High}

- number of respondents with insufficient level of self-reliance and/or responsibility, other traits are sufficient for the proper level of personal maturity;

number of respondents with insufficient level of self-reliance and/or responsibility and other insufficient traits. Link to disk.

Fig. 1. Levels of personal maturity development of air transport managers.

https://drive.google.com/file/d/13odP-eMNLxA8VHqbMB9nbvTU5HG85dNU/view?ts=604b4951. 
To continue analysis according to the set tasks it is interesting to determine not only overall level of the personal maturity development but also ratio of certain traits as prerequisite of adaptation strategies in the current crisis.

According to O.Shtepa, responsibility, life philosophy, self-reliance and creativity should be $8-10$ sn for the high level of personal maturity since they are underlying factors of personal maturity. It is clear from the result table that the majority of respondents has high level of creativity and is guided by certain life-philosophy in their actions. However, analysis displays that $66.2 \%$ respondents out of all respondents with critical level of personal maturity would achieve proper personal maturity in case of enhanced level of responsibility and/or self-reliance.

Pondering over the causes of this situation we should focus on the following: even respondents which are considered as very responsible in their routine or professional life are far from the high level of such traits as responsibility and/or self-reliance. The reason is that responsibility in certain professional obligations and responsibility as "personality's recognition of itself as an author and director of some project which can be some business, its personality and its life" are essentially different types of responsibility in quality and it manifests itself in different forms of adaptation to crisis. It means that responsible functioning of personality is not always feature of active life stance on its own choice of actions and their compliance with own visions, wishes and goals. For instance, responsibility can compensate for low level of creativity of personality.

Respondents are presumably to grow up at Soviet times or to be raised by the parents with authoritative Soviet beliefs and moral commitments (there is absolute majority among respondents) who retained unrevised patterns of actions according to some mainstream rules and regulations including attitude to the state, society, parents and other outer authorities which provide for obedience and submissiveness. Lack of necessity during the whole life to revise and refuse or accept again (making independent personal choice) rules and guidelines rooted in from childhood can be explained by abiding to the humanism concept, ethics, fairness based on philosophy of childhood life when person accepted the world unworried and joyful.

It means that ideology of Soviet society provided for raising of an ordinary personality who should follow certain rules as guarantee of predictable successful future. In its turn, it challenged personal choice and did not contribute to shaping of individual educational pathway and development of actively chosen personal skills. Striving for fancied and demonstrative prestige forced people to neglect their true wishes and abilities. Such ideology produced generation of career-minded people but hampered scientific and technical progress of the country. On the other hand, it is widely known that during framework crisis even the least toxic fundamentals of the personal life should be upgraded, i.e. reframed and re-assessed.

This process should lead to rising ability of person to recognize acceptance of any rules and principles in every particular situation "here and now". Besides, it is not enough to have mature personality in crisis and post-crisis period for the further development and effective functioning of personality. At the same time, psychological potential is crucial which can help to overcome crisis. Consequently, mature personality can be treated as resourceful if it finds force in itself to overcome life crisis.

Taking into account the aforesaid, a question arises of diagnostics of resource capabilities of the respondents - air transport managers. Results obtained through the Psychological Resourcefulness Questionnaire elaborated by O.Shtepa are presented in Figure 2. (link to disk).

The results have revealed that $15.2 \%$ respondents have low level of psychological resourcefulness, $73.6 \%$ have middle level and only $11.2 \%$ are characterized with high level of psychological resourcefulness development. 


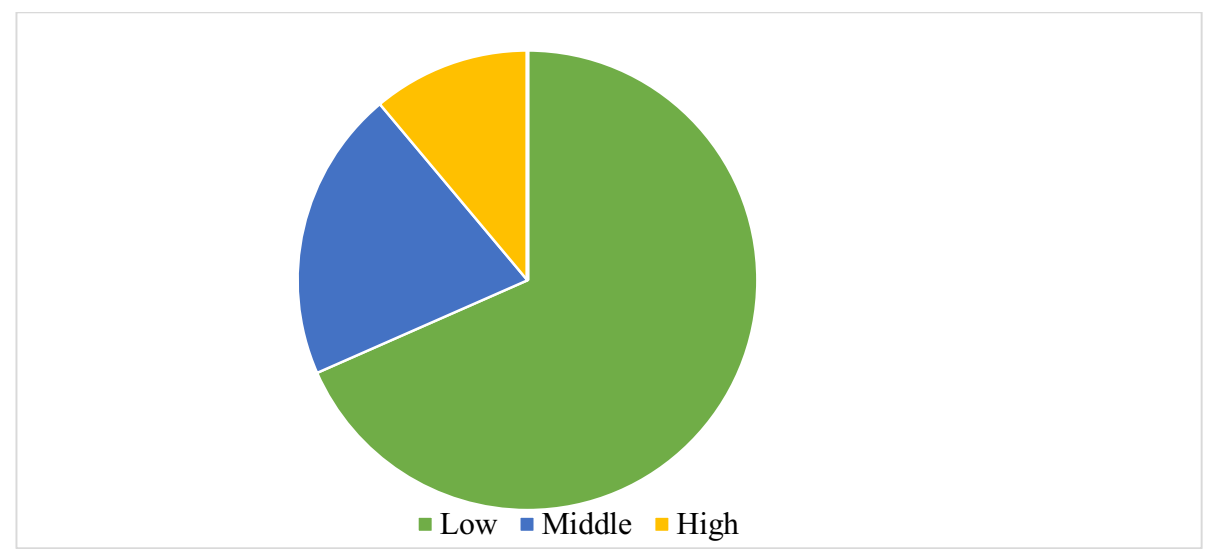

Fig. 2. Quantitative specifications of psychological resourcefulness of air transport managers. https://docs.google.com/document/d/1 fpOar4xQPQC6robXRH8qiulVYU65Ryc1/edit.

Taking into account that available psychological resources of personality do not warrant their application to overcome crisis it is vital for us to assess the level of actualization of psychological resources through the need for self-improvement, life abundance and intenseness, striving for cognition of outer and inner world. In addition, positive selfperception, clarification of goals, life energy as pre-requisite of self-development influences actualization of personal resourcefulness. Ultimately, personality should master mechanisms which help moving towards self-development.

To determine the ability to self-development and positive self-perception, the test Disposition Characteristics of Personal Self-Development was applied (elaborated by S.Kuzikova) which results are presented in Figure 3 (link to disk).

Quantitative outcomes of the test showcase that low level of self-development resource actualization is observed with $68.4 \%$ respondents, middle level with $20.05 \%$ and high level of self-development ability is typical for $11.1 \%$ respondents.

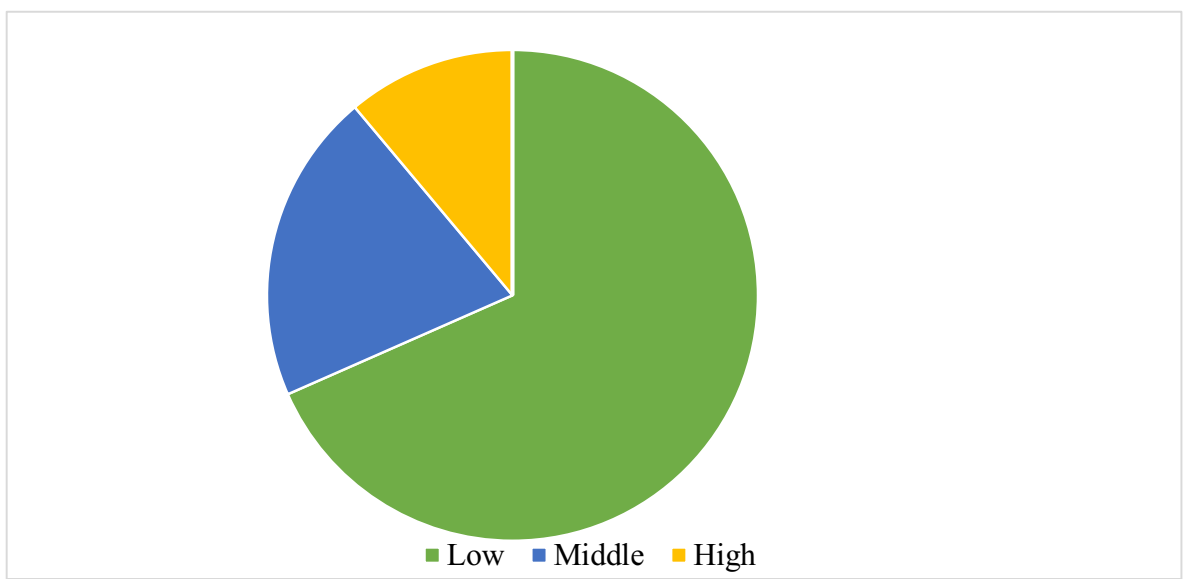

Fig. 3. Quantitative indices of the levels of development of inclination to self-development of air transport managers.

https://docs.google.com/document/d/1a_VrAsKTuD0Z5Ix7NqCCwd8ZKiE7Emti/edit

To determine sanogenic potential of the personal maturity of air transport manager's correlation was specified between personal maturity and overall personal ability to selfdevelopment and resourcefulness. Results are presented in Table 1. 
Table 1. Extract from the correlation matrix of quantitative indices of connection of personal maturity, resourcefulness and ability to self-development of air transport managers.

\begin{tabular}{|c|c|c|c|}
\hline & $\mathbf{A}^{\prime}$ & $\mathbf{B}^{\prime}$ & $\mathbf{C}^{\prime}$ \\
\hline $\mathbf{A}$ & 1.000 & $0.319^{* *}$ & $0.581^{*}$ \\
\hline $\mathbf{B}$ & $0.319^{* *}$ & 1.000 & $0.647^{* *}$ \\
\hline $\mathbf{C}$ & $0.581^{*}$ & $0.647^{* *}$ & 1.000 \\
\hline
\end{tabular}

Matrix legend: A - personal maturity, B - resourcefulness, $\mathrm{C}$ - ability to selfdevelopment, $*$ significance $\mathrm{p} \leq 0.05, * *$ - significance $\mathrm{p} \leq 0.01$.

Table 1 indices demonstrate low level of correlation between personal maturity and resourcefulness $(r=0.319, p \leq 0,05)$ and high level of correlation between ability to selfdevelopment and resourcefulness $(r=0.647, p \leq 0,01)$ and between ability to selfdevelopment and personal maturity $(\mathrm{r}=0.581, \mathrm{p} \leq 0,01)$. High indices of the mentioned correlations prove the possibility to enhance personal sanogenic potential due to correction of self-reliance and responsibility being the structural components of personal maturity, since these components determine level of development of personal maturity of respondents. Achievement of appropriate level of personal maturity within psychocorrection can be targeted through self-actualizing of the personal potential to selfdevelopment. Detected low indices of correlation between level of personal maturity and level of psychological resourcefulness are scientifically meaningful and valuable diagnostically for the further psychocorrection in terms of actualizing and recovery of personal resourcefulness. Under crisis of pandemic, the conventional sources of psychological resourcefulness are reduced substantially which should be taken into account by psychologists who elaborate psycorrection programs.

\section{Discussion}

Concept of the personal maturity in the context of air transport managers has nothing to do with age or experience but is related to two factors: resourcefulness and ability to selfdevelopment. Resourcefulness is defined as person's ability to actualize its own capabilities for personal growth. While ability to self-development is person's ability to regain personal competences when adapting to environment.

Presented research of personal maturity from the point of view of sanogenity for personality who endures crisis proved that only $7.5 \%$ respondents are characterized with high level of personal maturity. Personality's choice of the behavior strategy can be both conscious and unconscious. Effectiveness of this choice is considered to depend on person's ability to accept responsibility for its own activities and actions. If psychological functioning, namely, responsible attitude to settlement of crisis activates resourcefulness it can evolve in self-development. Integration of crisis occurrence into the context of life, experience, reframing of the developments in positive terms (glass is not only half-empty but half-filled at the same time) determine resource behavior strategy. However, dominating protective mechanisms in settlement of crisis provoke disintegration of personality, frustration, sense of futility, loss of sense of life.

Causes of delayed development of personal maturity and situational failing compensation can be considered convenient habitual patterns which allow person to avoid making own choice of strategic or tactical steps on the development pathway or identifying goals and being aware of its true wishes, thinking over self-development in the long run. 


\section{Conclusions}

Sanogenity of personal maturity of air transport managers does not depend on age or experience but is determined by the level of resourcefulness or ability to self-development.

Success in business or career is not identical to personal maturity development level. Subjective evaluation of successfulness and maturity by entrepreneurs does not meet the outcome of diagnostic measuring of $71.2 \%$ respondents. Substitution of notions of personal maturity and personal achievements, personal relevance and success is probable to take place. Personalities who are ultimately successful in life can be personally mature but in major cases scale of their success is determined by socially requested behavior factors, aspirations to prove personal relevance to the surrounding people, lucky combination of circumstances in the past etc., i.e. not inner but outer factors work.

Passiveness (unlike responsibility) and adaptive ability to act in the peculiar circumstances do not pose any threat in sustainable periods reducing only development and evolutionary changes while home task of mature personality forging as prerequisite of ability of transcending habits and practicing resistant behavior strategies uncompleted under lengthy multifaceted crisis becomes true problem with aftermath for person.

Along with it, if the personal maturity level is high and manifested in such structural components as responsibility and self-reliance resource, potential and aspiration to selfdevelopment are actualized. Due to this unconventional crisis is appraised not as disaster but as opportunity of growth and development of new business directions. Personal maturity under such circumstances being value and motivation core of personality serves as sanogenic potential during the crisis.

Suggested approach to personal maturity sanogenity definition through presented methods provides for fast and convenient way of obtaining proper psycho-diagnostic information on the client, its structure of personal maturity, available psychological resources for changes, ability to self-development. Taking into account demand for the assistance in the current pandemic and peculiarity of employment of air transport managers, lack of time for self-reflection etc. it enables elaborating psycho-correction problems in the shortest possible time and applying it and obtaining proper outcome.

The authors view prospects of the further theoretical and empirical research in factor analysis of certain indices of personal maturity, first and foremost, responsibility and selfreliance, their relation to other traits of personality. It would help clarifying psychocorrection targets for self-actualizing and determination of resourcefulness sources and relatively enhancing of sanogenic potential of personality which is today not sufficiently studied, the authors believe. We consider it enormously expedient in practical terms to create psychological toolkit to render efficient assistance to air transport managers, whose effective activities are underlying social stability under pandemic and country economic growth in post-pandemic period.

\section{References}

1. S.B. Kuzikova, Stratehii samorozvytku v zhyttievii kryzi osobystosti: resursnyi pidkhi (Sumy, Vyd-vo SumDPU imeni A. S. Makarenka, 2017)

2. B. Livehud, Krizisyi zhizni-shansyi zhizni (Kaluga, Duhovnoe poznanie, 1994) https://www.twirpx.com/file/557106/

3. R. Mehj, Iskusstvo psikhologicheskogo konsul'tirovaniya (Nezavisimaya gazeta «Klass», 1994) http://pedlib.ru/Books/1/0229/1_0229-1.shtml

4. A.A. Rean, A.R. Kudashev, A.A. Baranov, Psikhologiya adaptacii lichnosti. Analiz. Teoriya. Praktika (SPb., prajm-EVROZNAK, 2006) https://psy.su/psyche/projects/22/ 
5. C.S. Hall, G. Lindsey, Theories of Personality (N.Y., John Wiley and Sons, 1970, M., KSP+, 1997) Terminologicheskaya pravka V. Danchenko (K.: PSYLIB, 2005) http://psylib.org.ua/books/holli01/index.htm

6. O.S. Shtepa, Problemi suchasnoï psikhologiï 39, 380-399 (2018) http://nbuv.gov.ua/UJRN/Pspl_2018_39_33

7. O.S. Shtepa, Osobistisna zrilist': Model'. Opituval'nik. Trening (L'viv, Vidavnichij centr LNU imeni Ivana Franka, 2008) https://www.twirpx.com/file/650554/

8. S. D'Amour, L.R. Harris, S. Berti, B. Keshavarz, Attention, Perception, \& Psychophysics, 1-14 (2021) https://doi.org/10.3758/s13414-020-02228-3

9. P.L. Eriksson, M. Wängqvist, J. Carlsson, A. Frisén, Developmental Psychology 56(10) (2020) https://psycnet.apa.org/buy/2020-53941-001

10. V. Ponomarenko, I. Gontareva, Economic Annals-XXI 165(5-6), 4-7 (2017) https://doi.org/10.21003/ea.V165-01

11. O. Khokhlina, O. Lych, S. Gorbenko, A. Kazak, L. Pomytkina, IOP Conf. Series: Materials Science and Engineering 918(012175), 34-45 (2020) https://doi.10.1088/1757-89x/918/1/012175

12. L. Pomytkina, A. Gudmanian, O. Kovtun, S. Yahodzinskyi, E3S Web of Conferences 164, 31-43 (2020) https://doi.10.1051/e3sconf/202016410021 